\title{
EDITORIAL
}

\section{The OECD Unified Approach and the New International Tax System: A Half-Way Solution}

\section{INTRODUCTION}

The OECD Secretariat Proposal for a Unified Approach under Pillar One in the OECD Public Consultation Document ${ }^{1}$ regarding the allocation of taxing rights to Market States may have initially surprised many international tax lawyers and not only those who supported the supply-side approach. This is so even if the OECD January 2019 Policy Note and the OECD May 2019 Programme of Work, when handling Pillar One, already announced the acknowledgment of Market States' taxing rights by putting forward three proposals as a nexus: user participation, marketing intangibles, and significant economic presence. ${ }^{2}$ All of the proposals targeted taxation in the event of non-physical presence in the user/market jurisdiction. $^{3}$

A closer examination will demystify the concession to Market States. The latter will be entitled to residual taxing rights that are based on deemed profit (the deemed residual profit) for which a small percentage - probably up to $20 \%$ - of that deemed residual profit will be allocated to sales. The recently debated concept of value creation in its reference to users ${ }^{4}$ has not been taken into account in the proposal. An OECD policy decision to keep this intentional gap could lead to the maintenance or further enactment of unilateral taxes that are justified on user value creation.
The next paragraphs and pages are dedicated to a critical analysis of the OECD Unified Approach.

\section{The NeW NeXUS RULE}

The OECD Unified Approach officially proposes the right to tax by Market States and allegedly departs from the commonalities of the three above mentioned nexus alternatives (user participation, marketing intangibles, and significant economic presence) and suggests the introduction of a new nexus rule. This new nexus rule is the Market State in the absence of physical presence and possibly restricted to a minimum revenue threshold (for example, the EUR 750 million revenue used for countryby-country reporting). ${ }^{5}$ The Market State is further related to 'digital centric businesses which interact remotely with users'. 6

In the Summary of the Proposal, the 'new nexus' is described as 'a new nexus', 'a stand-alone rule - on top of the permanent establishment rule - to limit unintended spill-over effect on other existing rules'. 7 The new nexus would 'not be dependent on physical presence but largely dependent on sales'; and finally, 'it would be designed as a new self-standing treaty provision'.

The aforementioned spill over effect could occur for the following reasons: the Proposal intends to keep the cur-

\section{Notes}

OECD, Secretariat Proposal for a 'Unified Approach' Under Pillar One, Public Consultation Document 9 Oct. 2019-Nov. 2019 (OECD Publishing 2019), https://www.oecd.org/ tax/beps/public-consultation-document-secretariat-proposal-unified-approach-pillar-one.pdf (accessed 4 Nov. 2019). A Public Consultation Meeting on the proposed Unified approach to deal with Pillar One issues was held on 21 and 22 Nov. 2019.

OECD, Addressing the Tax Challenges of the Digitalisation of the Economy - Policy Note, as Approved by the Inclusive Framework. on BEPS on 23 January 2019 , OECD/G20 Base Erosion and Profit Shifting Project, 1-2 (OECD Publishing 2019), https://www.oecd.org/tax/beps/policy-note-beps-inclusive-framework-addressing-tax-challenges-digitali sation.pdf (accessed 4 Nov. 2019). OECD, Programme of Work to Develop a Consensus Solution to the Tax Challenges Arising from the Digitalisation of the Economy, OECD/G20 Inclusive Framework on BEPS, Ch. 2 (OECD Publishing 2019), https://www.oecd.org/tax/beps/programme-of-work-to-develop-a-consensus-solution-to-the-tax-challengesarising-from-the-digitalisation-of-the-economy.pdf (accessed 4 Nov. 2019).

OECD, supra n. 1 , at 4.

OECD, Tax Challenges Arising from Digitalisation - Interim Report 2018 Inclusive Framework on BEPS, OECD/G20 Base Erosion and Profit Shifting Project, Ch. 2 (OECD Publishing 2018), https://www.oecd-ilibrary.org/docserver/9789264293083-en.pdf?expires $=1572888009 \&$ id $=i d \& a c c n a m e=g u e s t \& c h e c k s u m=$ DF1D0CAC22179339F0BB6E509DB39C14 (accessed 4 Nov. 2019).

OECD, supra $\mathrm{n} .1$, at 7 , mno 20 and at 8 , mno 22 .

Ibid., at 7 , mno 19 .

Ibid., at 8, mno 23 .

Ibid., at 5, mno 15 . 
rent taxing rights (nexus) and transfer pricing rules applicable to supply-side States and permanent establishments and, by keeping the current nexus and allocation rules, the proposal further foresees their coexistence with the Market State nexus. The Proposal aims to limit unintended spill over effects by foreseeing three autonomous profit allocation methods - explained below - applicable to Market States. Each of these methods can be applied alone or simultaneously (however, each of them autonomously) depending on the facts and circumstances.

\section{3 ОBJect AND SCOPE}

Market States are related to 'user' States of highly digitalized businesses. This new nexus, according to the Proposal, results from political pressure ${ }^{9}$ and, therefore, is related to achieving 'fairness'. Furthermore, a highly digitalized business creating 'meaningful value' is equivalent to 'consumer-facing businesses': 'digital centric business which interacts remotely with users, who may or may not be their primary customers, and other consumerfacing businesses for which customer engagement and interaction, data collection and exploitation, and marketing and branding is significant, and can more easily be carried out from a remote location'. ${ }^{10}$

Data knowledge and knowledge discovery businesses (data collection and exploitation) are also covered as a result from the above.

It is not yet clear whether digital centric business interacting remotely with users and other consumer-facing business with significant customer engagement will correspond to or be broader than digital services as defined in the Proposal for a Council Directive on corporate taxation of a significant digital presence. ${ }^{11,12}$

In the case of correspondence, a digital centric business will be equivalent to 'services delivered over the internet or an electronic network, the nature of which renders their supply essentially automated and involving minimal human intervention'. ${ }^{13}$ Moreover, 'the mere sale of goods or services facilitated by using the internet or an electronic network (would) be excluded'. ${ }^{14}$
Considering the aforementioned definition, exclusions will encompass not only extractive industries (as clarified in the OECD Unified Approach) ${ }^{15}$ but also other 'not essentially automated' commodities such as agricultural and (brick and mortar) industrial products. According to the OECD Unified Approach, 'how the concepts of consumer products or consumer sales would deal with the supply of goods and services through intermediaries, the supply of component products and the use of franchise arrangements' still has to be clarified. ${ }^{16}$

Consumer-facing businesses will be broader than Business to Consumer (B2C) digital centric sales and will cover Business to Business transactions (B2B) so that allocation of profits to Market States is not circumvented by the use of distributers that do not belong to the consolidated group. ${ }^{17}$

However, the Unified Approach may go beyond the above-mentioned 'essentially automated' commodities ${ }^{18}$ as it states that '(f)urther discussion should also take place to consider whether other sectors (e.g. financial services) should also be carved out, taking into account the tax policy rationale as well as other practicalities'. ${ }^{19}$

The concept of 'consumer-facing businesses' appears to only refer to individuals, companies, or any other groups that are considered as taxpayers under national legislation. It would be advisable to clarify that consumer-facing business, consumer sales, and consumer products also cover 'automated' consumers, robots, or any future form of artificial intelligence held in the broad and strict senses.

Moreover, it would be preferable to restrict the nexus of Market State to 'essentially automated' commodities instead of attempting to broaden it to other non-materialized services such as financial services unless automation also occurs in the latter services.

\section{RING-Fence}

In 2018, one of the core discussions in the OECD Interim Report and academic literature was related to the option between ring fencing the digital economy for tax

\section{Notes}

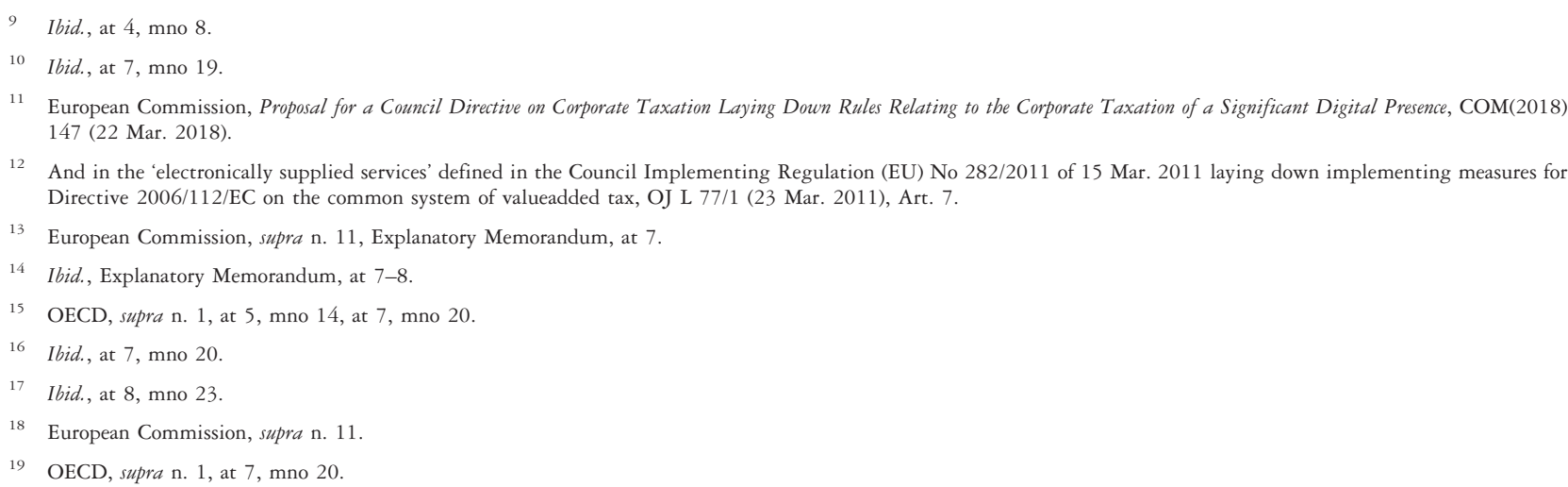


purposes $^{20}$ and thereby possibly taxing some specific business models that are identified as highly digitalized ${ }^{21}$ or setting up a new international tax system that acknowledged taxing rights to Market States. ${ }^{22}$ However, there was no consensus on how to move forward:

373. While acknowledging these divergences, members of the Inclusive Framework agree that they share a common interest in maintaining a single set of relevant and coherent international tax rules, to promote, inter alia, economic efficiency and global welfare. As such, they have agreed to undertake a coherent and concurrent review of the two key aspects of the existing tax framework, namely the profit allocation and nexus rules that would consider the impacts of digitalization on the economy.

374. Further work will need to be carried out on the analysis of the value contribution of certain characteristics of highly digitalized business models as well as digitalization more broadly, and to inform that debate, technical solutions would also be explored to test the feasibility of different options with respect to the profit allocation and nexus rules. This process will include gathering input from a broader group of stakeholders including business, civil society and academia. An update on this work will be provided in 2019, as members work towards a consensus-based solution by 2020. Throughout these stages of work, it will be important to continue to monitor the latest developments: from the evolution of new technologies and rapidly evolving business models, to the adoption and impact of countries' legislative proposals that aim to address these challenges. ${ }^{23}$

At the time, any taxing rights that are acknowledged for Market States would be linked to some concept of value creation. $^{24}$

The OECD Unified Approach is half-way between digital taxes and a new international tax system allocating taxing rights to the Supply Side and Market States. By referring to bighly digitalized business and consumer-facing business, the new nexus in the Unified Approach does not cover all types of business, therefore, it ring-fences the objective (the tax object) and subjective scopes (the taxpayers).

This is valid even if the Unified Approach does not specifically refer to types of digital models but will instead devise exclusions from the scope and recommends the structuring of a threshold as a primary indicator of sustained and significant involvement in the jurisdiction. The outcome achieved by exclusions and a threshold versus enumeration of specific business models may currently be equivalent but will be different in the future as the former contains a dynamic approach: if jurisdictions establish a threshold, future 'highly digitalized' business models will be covered without a need to amend the terms in a bilateral or multilateral tax treaty(ies).

As mentioned in the following paragraphs, the coexistence of three methods of allocation of taxing rights (three-tier profit allocation rules) will also contribute to ring fencing the economy for tax purposes.

\section{Profit allocation rules}

The proposal consists of a three tier profit allocation mechanism that differentiates types of amounts:

'Amount A - where a share of deemed residual profit is allocated to market states according to formulary apportionment;

Amount B - which grants a fixed remuneration for baseline marketing and distribution functions that take place in the market jurisdiction; and

Amount $\mathrm{C}$ - binding and effective dispute prevention and resolution mechanisms relating to all elements of the proposal, including any additional profit where in-country functions exceed the baseline activity compensated under Amount B. ${ }^{25}$,

The following features concerning profit allocation rules as proposed in the Unified Approach are to be highlighted.

First, attribution of tax revenue to the Market State and related to 'highly digitalized businesses' will result from formulary apportionment and sales and not from some deemed value creation by users even if there is a reference

\section{Notes}

20 A. Báez Moreno, A Note on Some Radical Alternatives to the Existing International Corporate Tax and Their Implications for the Digital(ized) Economy, 46(6/7) Intertax 560-564 (2018); Y. Brauner, Taxing the Digital Economy Post-BEPS, Seriously, 46(6/7) Intertax 462-465 (2018); M. F. de Wilde, Comparing Tax Policy Responses for the Digitalizing Economy: Fold or All-in, 46(6/7) Intertax 466-475 (2018); M. P. Devereux \& J. Vella, Debate: Implications of Digitalization for International Corporate Tax Reform, 46(6/7) Intertax 550-559 (2018); A. P. Dourado, Debate: Digital Taxation Opens the Pandora Box: The OECD Interim Report and the European Commission Proposals, 46(6/7) Intertax 565572 (2018); L. Spinosa \& V. Chand, A Long-Term Solution for Taxing Digitalized Business Models: Should the Permanent Establishment Definition Be Modified to Resolve the Issue or Should the Focus Be on a Shared Taxing Rights Mechanism?, 46(6/7) Intertax 476-494 (2018); A. Turina, Which 'Source Taxation' for the Digital Economy? 46(6/7) Intertax 495519 (2018); OECD/G20 Interim Report 2018, cit., e.g. at 18, mno 15, at 166, mno 370, at 167, mno 375, at 212, mno 510 ; and the national taxes (seen preferably as interim measures): at $137-164$

21 See OECD/G20 Interim Report 2018, cit., where business models in the digital economy are analysed: e.g. Ch. 2, at 43-81, and (interim) unilateral measures, Ch. 6, at 137 et seq.; See European Commission, supra n. 11.

22 See OECD, supra n. 4, e.g. at Ch. 5, at 65 et seq

23 Ibid., at 166.

24 Ibid., Ch. 5 , at 65 et seq.

25 OECD, supra n. 1, at 6, mno 15 
to highly digitalized business creating 'meaningful value' and to 'consumer-facing businesses'.

Second, the beginning point of the proposal is the 'amounts to be shared'. The purpose of these 'amounts' is to establish an hierarchy among States, and (attempt to) satisfy Market States, but not to actually create a level playing field among States in the digital economy.

Third, by excluding some income/activities from the deemed residual profit Amount A, the proposal differentiates among types of income, therefore, it ring-fences the economy.

Fourth, even though the Market State is a new nexus on its own and related, as discussed above, to highly digitalized business and consumer-facing business, the three-tier profit allocation mechanism attributes amounts $\mathrm{A}, \mathrm{B}$, and C to a broader category of Market State. This broader category includes the current 'Source State' under bilateral tax treaties. The Appendix also refers to 'the new taxing right (as) increase(ing) the amount of business profits allocated to market jurisdictions', and 'three possible types of taxable profit that may, according to the circumstances in any particular case, be allocated to a market jurisdiction (which, in some instances, is the location of the user) ${ }^{26}$

Fifth, the complexity is high. Too high. Taking into account the relevance of the current digital economy and its expected future developments, the three-tier mechanism does not allocate much tax revenue to the Market States (the latter either held as a strict or broader category).

\section{The DeEmed Residual PROFIt AND INTERNATIONAL DOUBLE TAXATION}

The new nexus would be linked to a 'new profit allocation rule going beyond the arm's length principle'. ${ }^{27}$ This profit allocation rule linked to the Market State is the 'deemed residual profit' as determined in a formula according to sales (a part of the deemed residual profit resulting from sales) and a revenue threshold.

The deemed residual profit of a multinational business is to be assessed on a group or a business line basis, and it 'would represent the profit that remains after designating a deemed routine profit on the activities of the group or business line, 28 . It would have application to both profits and losses, however, specific rules may be considered for the treatment of losses - 'claw-back' or 'earn-out' mechanism. ${ }^{29}$
This approach "would replicate features of both the residual profit split (RPS) by introducing a threshold on profitability and excluding the remuneration of routine activities, and the fractional apportionment method, by relying on formula-based calculations, ${ }^{30}$

Formula based calculations to compute Amount A could rely on a modified earnings before interest, taxes, depreciation and amortization (EBITDA) that is assessed on the basis of financial consolidated accounts; routine profit can be determined on the basis of a specific threshold and fixed rates (to a specific business line, it can be attributed $\mathrm{x} \%$ of routine profit); residual routine profit will be the allocated part on the basis of a formula and taking sales into account. Subsequently, B and C amounts are based on the transfer pricing rules even if adapted.

The revenue threshold accompanying the new nexus for business models involving remote selling ' ... would also apply to groups that sell in a market through a distributor ( ... related or non-related ... . ... important to ensure neutrality between different business models, and capture all forms of remote involvement in the economy of a market jurisdiction'. ${ }^{31}$ Thus, as previously mentioned, it encompasses both $\mathrm{B} 2 \mathrm{~B}$ and $\mathrm{B} 2 \mathrm{C}$ transactions.

The new nexus is autonomous from source rules linked to permanent establishments.

Market States can be Market States alone (Amount A) with no physical presence justifying taxation according to the Multilateral Instrument (MLI) permanent establishment rules. In this case, it must be determined whether the non-resident company makes sufficient sales in the Market State in order to meet the revenue threshold.

However, Market States can also be Market States (Amount A being applicable) and source States with physical presence (the income of which is taxed as amount $\mathrm{B}$ or according to transfer pricing rules if the company's function in the Market State goes beyond marketing and distribution functions).

Thus, the new nexus will also be applicable where there is, simultaneously, a digital centric business and physical presence in the Market State by a permanent establishment or an affiliate. In this case, taxation will occur according to Amounts $\mathrm{A}$ and $\mathrm{B}$ or $\mathrm{A}, \mathrm{B}$, and $\mathrm{C}$.

Taxation of Amounts A and B will be less complicated as they both rely on 'deemed profit' methods, profits will be 'fixed' and, therefore, by definition, do not overlap and do not lead to double taxation. In contrast, taxation of Amounts A, B, and C will lead to double taxation. This is a result of the combination of the arm's length standard

\section{Notes}

\footnotetext{
26 Ibid., at 13 , mno 50

27 Ibid., at 5 mno 15.

28 Ibid.

29 Ibid.

30 Ibid., at 13 , mno 52

31 Ibid., at 8, mno 23.
} 
based on taxation of net profits with the taxation of deemed profits.

If there is a permanent establishment (the profits of which will be allocated according to Article 7) or an affiliate (the profits of which will be allocated according to Article 9) and no consumer-facing business related to highly digitalized models and without physical presence, there is no need for the new nexus rule. In this case, profit allocation rules corresponding to Amount B or Amounts $\mathrm{B}$ and $\mathrm{C}$, as further explained below, will be applicable.

In the event that there is physical presence of a multinational in the Market State that is responsible for marketing and distributing the group's product or service (assume a digital service such as streaming services), ${ }^{32}$ a fixed remuneration for baseline marketing and distribution functions that occur in the market jurisdiction can be agreed upon (Amount B).

If the Market State also claims additional profits, according to Transfer Pricing (TP) rules as well as the Function, Assets and Risks (FAR) and Development, Enhancement, Maintenance, Protection and Exploitation of Intangibles (DEMPE) formulas, the Unified Proposal stresses that the Market State 'would be subject to robust measures to resolve disputes and prevent double taxation'.

The Unified Approach apparently seeks to satisfy all interested parties: the residence nexus that targets Supply-Side States; the permanent establishment (source) nexus that also targets, to a great extent, Supply-Side States and not necessarily Market States as a sales or destination State will also be kept; and the Market States as the new nexus related to allocation of taxing rights according to Amount $\mathrm{A}$ in the case of highly digitalized models and consumer-facing business without physical presence.

The proposal allegedly has two primary advantages: to limit the disruption of the conventional transfer pricing standard that is applicable to routine activities ${ }^{33}$ and to use simplified conventions facilitating the administration of the new profit allocation rules alongside the transfer pricing rules. ${ }^{34}$ None of these advantages compensate the disadvantages (mainly complexity and insignificant revenue for the Market State) resulting from the Proposal.

\section{Half-way solutions}

In fact, one of the major problems with the Proposal lies in the fact that it is a half-way solution similar to those several amendments to domestic legislation destroying consistency of tax systems and when the outcome is, at the least, of enormous complexity. Allocating a portion of the deemed residual profit to the Market State - or a halfformula based solution - is an acknowledgement of the failure of net income tax (taxation of real income) in the international setting and an acknowledgment of the insufficiencies of arm's length for a fair attribution of income to Market States. The deemed residual profit is, in fact, an indirect method of assessing income as it is based on presumptions and does not rely on real or net income.

Transfer pricing rules will continue to be in force and did not evolve into a full formula based approach, which would have been desirable. In this context of transfer pricing with the predominance of the Supply-Side State, taxation of gross income in the Market State by means of a withholding tax is also not accepted. This would be an easier solution but would generally imply acknowledging more taxing rights to the Source States either as a withholding tax on services following Article 12-A of the UN Model Convention or by ring-fencing the economy.

This withholding tax would also recommend the adoption of a credit method together with worldwide taxation in order to reduce international double taxation. In contrast, withholding taxes are not excluded in the Unified Approach, however, they are applied on the deemed residual profit.

\section{ROUTINE tRANSACtions, ARM'S LENGTH AND SUPPLY-SIDE STATES}

The proposal still relies on the arm's length standard for routine transactions, complementing it with formula based solutions associated with sales in situations in which tensions have increased in relation with the digitalization of the economy. This is an evolutionary and not revolutionary approach, as expected, ${ }^{35}$ but it is still favouring Supply-Side States that determine what the routine profits are and what is left for the Market States.

The Proposal divides the profit in a hierarchical order, according to the State category (Supply-Side, Source, Market) instead of acknowledging world profit and sharing it among implicated States. In fact, and although the Proposal is put forward as an evolution of the arm's length standard towards formulary apportionment, sales are not generally equated in the same terms as capital, intangibles, and production (capital and intangibles corresponding to FAR and, therefore, considered as the relevant factors for Supply-Side States). Taxation in the Market State that is attributable to sales only occurs as a second step as a subsidiary and indirect method: under the

\section{Notes}

32 Ibid., at 11

33 Ibid., at 13, mno 52.

34 Ibid.

35 A. Martín Jiménez, BEPS, the Digital(ized) Economy and the Taxation of Services and Royalties, 46(8/9) Intertax at 620-638 (2018). 
Unified Approach, sales are only relevant as a reallocation of a portion of non-routine profit - deemed residual profit - as proposed by the marketing intangibles and user participation proposals. ${ }^{36}$ Inclusion of Market States in the transfer pricing rules' logic would have required adoption of the significant economic presence approach that took into account all profits - routine and nonroutine - as the starting point. ${ }^{37}$

Also, to foresee the deemed residual profit in simplified conventions will imply determination of deemed profit according to specific business lines, a huge technical work with enormous policy problems that the OECD will apparently carry forward. It is unlikely that the outcome will be meaningful.

\section{ConCluding Remarks}

The new nexus rule and the allocation of taxing profits rules do not create a level playing field (they operate as defensive rules against Market States): Market States are at the bottom-line and claim a right to residual profit and, if they claim taxes related to the source rules including FAR and DEMPE, strong measures 'binding and effective dispute resolution mechanisms' related to amounts A, B, and $\mathrm{C}$ will be equated.
The new nexus linked to the concepts of digital centric business, consumer-facing business, and to a threetier profit allocation mechanism is overly complex, ring-fences the economy, and does not allocate relevant revenue to the Market States in the end.

The Unified Approach is half-way between effective taxation of ability-to-pay in the current digitalized economy: it continues to rely on transfer pricing that does not satisfactorily tax intangibles; it adopts sales as complementary to transfer pricing but does not go into a formula based taxation system; and sales (the Market State) do not fully reflect the value of intangibles.

The Unified Approach aims to avoid proliferation of uncoordinated unilateral tax measures including measures taxing gross revenues. Its complexity and reliance of Amount $A$ on a small proportion of sales will probably not achieve its purpose.

It would be much more preferable to evolve into full formulary apportionment without ring-fencing highly digitalized business even if the portion allocated to sales were lower than the portion allocated to Supply-Side States.

Ana Paula Dourado Editor-in-Chief 